SPRINGER BRIEFS IN ENVIRONMENT, SECURITY, DEVELOPMENT AND PEACE 22

Cecilia Ng Editor

Gender Responsive and Participatory Budgeting Imperatives for Equitable Public Expenditure 


\section{SpringerBriefs in Environment, Security, Development and Peace}

Volume 22

Series editor

Hans Günter Brauch, Mosbach, Germany 
More information about this series at http://www.springer.com/series/10357 http://www.afes-press-books.de/html/SpringerBriefs_ESDP.htm

http://www.afes-press-books.de/html/SpringerBriefs_ESDP_22.htm 
Cecilia $\mathrm{Ng}$

Editor

\section{Gender Responsive and Participatory Budgeting}

Imperatives for Equitable Public Expenditure

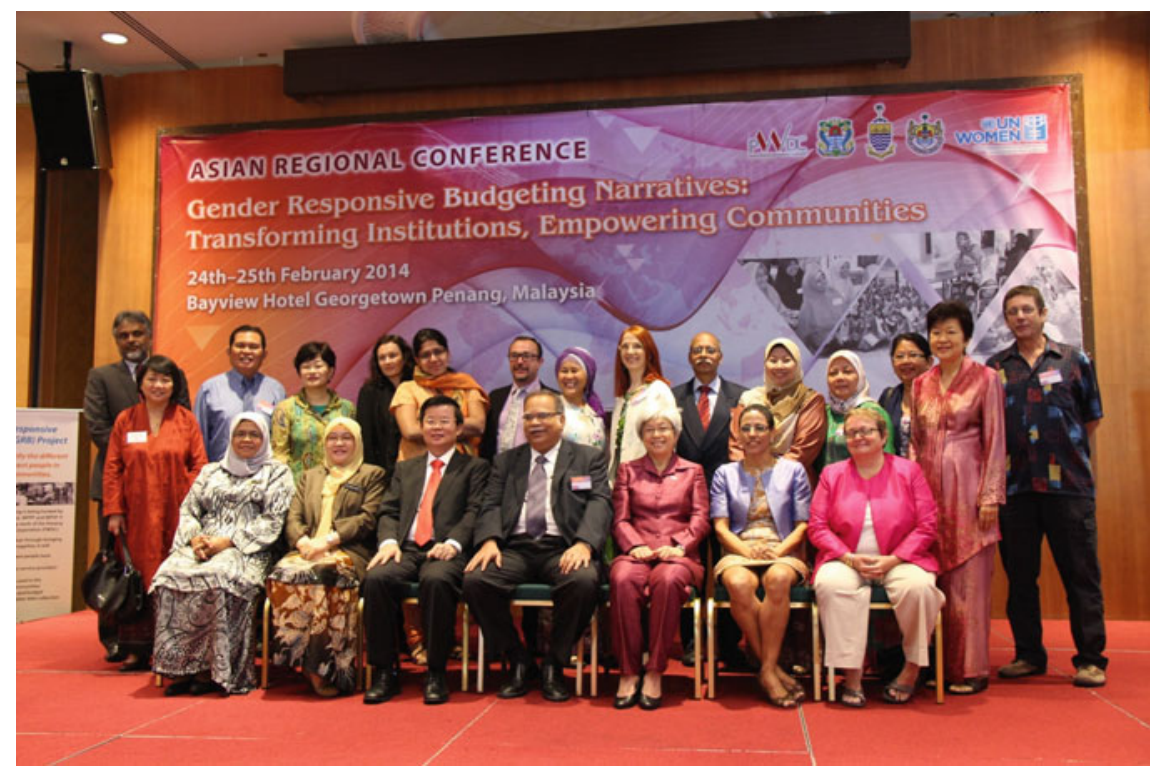

算 Springer

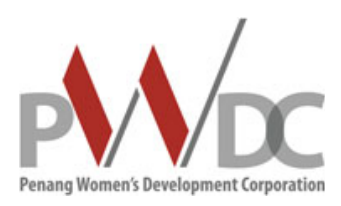


Editor

Cecilia Ng

Penang Women's Development Corporation

Penang

Malaysia

Licensed in Malaysia and Singapore to:

Strategic Information and Research Development Centre

No. 2 Jalan Bukit 11/2, 46200 Petaling Jaya, Selangor, Malaysia

Fax: (60) 379578343

Email: gerak@gerakbudaya.com

Website: http://sird.gerakbudaya.com

for exclusive distribution in Malaysia and Singapore.

ISSN 2193-3162

ISSN 2193-3170 (electronic)

SpringerBriefs in Environment, Security, Development and Peace

ISBN 978-3-319-24494-5 ISBN 978-3-319-24496-9 (eBook)

DOI 10.1007/978-3-319-24496-9

Library of Congress Control Number: 2015950050

Springer Cham Heidelberg New York Dordrecht London

(C) The Author(s) 2016

This work is subject to copyright. All rights are reserved by the Publisher, whether the whole or part of the material is concerned, specifically the rights of translation, reprinting, reuse of illustrations, recitation, broadcasting, reproduction on microfilms or in any other physical way, and transmission or information storage and retrieval, electronic adaptation, computer software, or by similar or dissimilar methodology now known or hereafter developed.

The use of general descriptive names, registered names, trademarks, service marks, etc. in this publication does not imply, even in the absence of a specific statement, that such names are exempt from the relevant protective laws and regulations and therefore free for general use.

The publisher, the authors and the editors are safe to assume that the advice and information in this book are believed to be true and accurate at the date of publication. Neither the publisher nor the authors or the editors give a warranty, express or implied, with respect to the material contained herein or for any errors or omissions that may have been made.

Cover photo: Penang State and Local Government leaders with speakers and the main organising committee of the GRB Conference. Seated from left are Maimunah Mohd Sharif (President of the Sebarang Jaya Municipal Council), Patahiyah Ismail (Mayor of the Penang Island City Council), Chow Kon Yeow (Penang State Exco member and Chair of the Conference Coordinating Committee), Prof. Dr. Ramasamy (Deputy Chief Minister II), Chong Eng (State Exco member and Chair of the Penang Women's Development Corporation) and Roberta Clarke (Regional Director, UN Women Regional Office for Asia and the Pacific). The permission was granted by PWDC who provided the photo. More on this book is at: http://www.afes-press-books.de/html/SpringerBriefs_ESDP_22.htm

Copyediting: PD Dr. Hans Günter Brauch, AFES-PRESS e.V., Mosbach, Germany

Language Editing: Ms. Veena N., Bangkok, Thailand

Printed on acid-free paper

Springer International Publishing AG Switzerland is part of Springer Science+Business Media (www.springer.com) 


\title{
Chapter 3 \\ Women in Budgeting: A Critical \\ Assessment of Participatory Budgeting \\ Experiences
}

\author{
Giovanni Allegretti and Roberto Falanga
}

\begin{abstract}
Budgeting has for too long been considered a technical arena for highly skilled elites. Participatory Budgeting (PB) opens up the field and creates a space for local communities to discuss the equitable distribution of resources. However, gender has not been at the forefront of the PB debate. On the other hand, gender responsive budgeting has had its own growth trajectory, often not including participatory methods. The chapter highlights possible intersections between PB and gender mainstreaming and notes PB's potential in addressing issues of gender mainstreaming and social justice, following dialogues with other complementary democratic innovations.
\end{abstract}

Keywords Participatory budgeting - Porto Alegre - Democratic innovation • Co-governance

\subsection{Introduction}

Participatory budgeting (PB) is today considered one of the most successful democratic innovations of the past 25 years, with almost 2,800 active instances around the planet (Sintomer et al. 2013). Since the first experience took shape in Brazil at the end of the 1980s, PB has been considered as a mechanism to promote

Giovanni Allegretti, Senior Researcher at the Centre of Social Studies, Faculty of Economics, Coimbra University, Portugal. Email: allegretto70@gmail.com.

Roberto Falanga, Postdoctoral Fellow, Mobilizing the Potential of Active Ageing in Europe, European FP7 Project, Institute of Social Sciences, University of Lisbon, Portugal. Email: roberto.falanga@hotmail.it.

C. Ng (ed.), Gender Responsive and Participatory Budgeting,

SpringerBriefs in Environment, Security, Development and Peace 22,

DOI 10.1007/978-3-319-24496-9_3 
trust and overcome the legitimacy crisis of representative institutions by encouraging citizens' participation and co-governance in decision making on economic and financial issues. ${ }^{1}$

While the variety of PB designs has not been sufficiently studied, PB could likely be best described as an ideoscape ${ }^{2}$ (Appadurai 1991). This suggests a model that travels around the world and becomes real only through local experiments. Its diversity contributes to continuous change through concrete localized implementations and the different meanings ascribed to $\mathrm{PB}$, according to specific instruments and procedures used to shape its organizational architecture. In spite of these variations, global PB experiments have some minimum common denominators and pivotal principles that make $\mathrm{PB}$ recognizable among other participatory innovations that dialogue with it.

Participatory budgets are regarded as important innovations and experiments that investigate new possible forms of governance. Their intrinsic value seems higher in the aftermath of the international crises affecting economies and the legitimacy of representative institutions that appear incapable of challenging and regulating markets. PB could, therefore, become an important space to discuss the distribution of (scarce) resources. It could also contribute to the repolitization of a field - that of budget elaboration - that has for long been considered a mere technical reservoir for highly skilled elites, increasingly gaining strategic importance in public deliberation. PB seems to offer an opportunity to challenge the vision of a neoliberal economy as an inescapable destiny, establishing a richer vision of economic sciences as a field of alternative possible choices that could be addressed in different ways.

Moreover, it is time today for deeper reflections on possible interrelations between PB and its potential in addressing issues of gender mainstreaming and social justice. This issue is undoubtedly relevant, especially if we examine the 25 year history of PB. This paper aims to depict the substantial lack of interest in possible intersections between PB and gender mainstreaming policies. The next section clarifies some issues related to gender sensitive approaches and their substantial absence in the history of

\footnotetext{
${ }^{1}$ This text owes part of its reflections to the project 'Participatory Budgeting as innovative tool for reinventing local institutions in Portugal and Cape Verde: A critical analysis of performance and transfers' (PTDC/CS-SOC/099134/2008, funded by FEDER - COMPETE and FCT). We want to deeply thank Craig Laird for reading the text with patience and correcting its grammar imperfections.

${ }^{2}$ When Appadurai developed his five dimensions for reading global cultural economy (ethnoscape, technoscape, financescape, mediascape, and ideoscape), he tried to demonstrate that globalization is not merely rooted in the expansion of global capitalism within core-periphery models and does not produce only a homogenized global culture. He sought to demonstrate that modernity circulates through geographic, diasporic, imaginary and local spaces producing several irregularities of globalization (Martínez 2012). Under this perspective, the suffix '-scapes' is used to parallel the variable and often uneven terrain of landscapes to that of uneven global modernization. 'Ideoscapes' can be seen as attempts to capture State power and therefore also consist of counter-ideologies in opposition to modern, dominant political discourses. In this light, we imagine $\mathrm{PB}$ as an ideoscape, born in Latin America and hybridized during its circulation around the world.
} 
PB development, notably in its dialogue with other complementary democratic innovations. Following this, the third section proposes some counter stream examples of PB - which constitute a sort of journey around the planet-where a gender sensitive perspective introduced consistent and remarkable innovations. On the basis of these experiences, the concluding section provides some recommendations, taking the shape of a research agenda for improvements in PB and its complementarity with other democratic innovations. It concludes with some policy-oriented suggestions for designing a different future for this democratic innovation.

\subsection{Is PB Gender Sensitive?}

Unfortunately, few of the nearly $2,800 \mathrm{~PB}$ cases show a real sensitivity to gender-related issues, except for some cases in Latin America. The first comparative research on European PB experiences in the past decade (Sintomer/Allegretti 2009, 2014; Sintomer/Ganuza 2011) clearly stated that participatory budgets in the region almost never contribute to changing the social roles of men and women. This was despite the claim that almost everywhere, women appear to be involved in them to a considerable degree, often representing 30-50\% of those involved, with an upward trend when the process becomes more institutionalized. This research noted that in most cases, nothing much was done to facilitate equal participation, even when relevant political female figures attempt (or have attempted) to carry the PB idea forward at the national level, almost constructing their political profile on the basis of the participatory theme. This was true of Segolène Royal (governor of the French region of Poitou Charentes and inventor of the most renowned High School PB) and UK ex-Minister Hazel Blears, who strengthened the PB network in her country, giving it national visibility.

In Africa, Asia and (to a lesser extent) North America and Oceania, the situation does not appear more promising. Certain experiences are exceptions (as in China or Australia) when random selection was applied as a main feature of PB procedures, and gender was used as a variable to select participants for budgetary decisional committees. In these cases, the focus has mainly been on the quantitative aspect of women's presence in the participatory processes. Issues related to power relations in society and the equal valorization of women's voices, their ideas and their decisional and oversight capacities were hardly considered.

The question is: what explains the weak commitment of PB to the adoption of a gender sensitive perspective or the inclusion of gender mainstreaming as a pivotal goal? No single factor explains the negative convergence of so many different cities and political and cultural contexts. However, some possible explanations are often recurrent. These include:

(1) Rarely have transparency and accountability been valued as a real centre of interest for PB. This implies that a careful analysis of public spending is generally not associated with measures of affirmative action that promote social inclusion. 
(2) Institutions and procedures responsible for overcoming gender inequality remain fragmented and isolated in many local contexts. They are often in charge of specific policies for specific targets instead of being permitted to insert these goals into a larger spectrum of policies. Furthermore, such gender sensitive structures are often coordinated by parties or officials who are considered marginal to the powerful architecture of governing coalitions.

(3) Often gender budgeting procedures are considered a posteriori documents that can contribute more to the understanding of dynamics established to fight gender inequalities than to forge such dynamics by creating participatory arenas to set and fund priorities shaping antidiscrimination and gender empowering policies. As a result, they often act more as sort of gender balance. Such a limited vision diminishes the potential of gender budgeting and reduces spaces to influence the transformation of resource distribution when preliminary budgets are being drafted.

(4) Most gender sensitive actions are viewed as being addressed to women instead of opening new forms of dialogue between women and men. Hence, men often continue to act according to patriarchal/chauvinistic approaches, neither being targeted nor involved directly (as beneficiaries and co-producers) in policies and campaigns oriented towards addressing new visions of relations between women and men.

(5) Self-censorship of women (in social contexts) is often disregarded as an indicator of exclusion, because it is presumed to be voluntary. However, from the perspective of the constraints posed by cultural traditions to the transformation of power relations in society, this phenomenon is undeniably dangerous and recurrent even in participatory processes.

(6) Women's equality has rarely been read in the setting of public participatory policy making innovations from the perspective of the impact of multiple exclusions. Thus, it has not only been separated from disability, single parenthood, age, ethnicity, race or socio-economic segregation, but also from gender orientation concerns.

This complexity of reasons underlines the plurality of agents responsible for PB falling short of its potential in terms of effectiveness. Administrative institutions, i.e. their elected officials and technical staff, are not alone in promoting a diluted PB model that lacks real interest in promoting gender equality and women's empowerment. Civil society also actively dilutes PB as do, to a large extent, universities and other research institutions. As clearly underlined by Santos (2007), several studies in the past decades have often neglected data collection and a gender sensitive perspective when analysing participatory processes and evaluating their effectiveness and efficacy, despite setting out to assess their redistributive effects and their capacity for social inclusion.

In spite of recognizing that many social, political and economic transformations owe a lot to the growing role of women in social life (Avritzer 2007) that contributed to re-democratization in many countries and benefited from them (Alvarez 1991), several studies on PB and other participatory tools of governance innovation have not been analysed for their gender sensitiveness. If this is true, we must 
recognize - with Santos (2007: 240) — that 'the studies on participatory democracy look blind to the gender differences and women's participation' to the same extent that 'feminist studies on women and/in politics seem everyday more focused on the presence of women in representative institutions, and not in the participatory ones'.

Santos (2007: 242), criticizing the weight literature assigns to quotas and the numerical presence of women in representative institutions, agrees with Araujo's (2002: 150) hypothesis that considerable affirmative action has occurred in the context of neoliberal political reforms. In view of this, Santos suggests that a new research agenda on participatory processes must be based on critical theory with feminist perspective. This must start with Scott's definitions of gender as (1) a constitutive element of social relations, based in differences perceived by sexes (Scott 1988: 42), which imagines gender as a category or a variable of analysis of relations, positions and social relations; and (2) a primary field through which power is articulated (Scott 1988: 43-44), and which sees gender as an attribute of culture.

The lessons that Santos takes from the analysis of so many missing opportunities in valuing the presence of gender sensitive elements in participatory processes are interesting. She stresses the need to take into account a minimal numeric presence of women in every process (reachable through quotas and other affirmative action) and an identity feminist politics that guarantees women's expression and interests. The latter elements represent a widely differentiated evolutionary social category in permanent transformation. The presence of women in participatory processes must translate into a real representation and redistribution of their interests which are clearly plural and complex, thus constituting an open question to be constantly re-analysed.

The need to acquire such a complex perspective requires a preliminary act (Alves/Viana 2008: 45), i.e., abandoning the acceptance — absorbed equally by men as well as by women - of a sort of natural incapacity of women to play a role in the public domain and develop a political intervention. Such an acceptance is often so strong that it succeeds in identifying politics, including participation and collective action, 'as something belonging to [the] male world', to the point that men feel almost 'naturally empowered to deal with politics, exert power, occupy public space...'. Likewise, men show progressively less interest in investing time on small decisions that no longer guarantee solid power.

This is evidenced in a recent comparative analysis of participatory budgets in Spain, Uruguay and the Dominican Republic, where Gutiérrez-Barbarrusa (2012) encountered and described a phenomenon of feminization of PB spaces, especially when resources are shrinking.

\subsection{Counterstream Experiences that Link PB to Gender Sensitive Approaches}

Fortunately, the above reflections do not represent the entire panorama of global participatory budgets. In the past 25 years, institutions at local and international levels, mainly in Latin America, have tried to promote a different approach to PB 
and goals of gender mainstreaming. Two main types of gender sensitive (or, at least, women sensitive) PB have occurred when:

(1) Local institutions (often stimulated by supra-local or even transnational networks and organizations) promoted studies on the effects of PB on gender equality or to maximize synergies between existing PB and other processes to promote antidiscrimination visions or affirmative action for gender mainstreaming. Unfortunately, although highly interesting in terms of cultural vision, many of these experiences have only been episodic, producing with some exceptions limited effects on the transformation of PB and its output, and rarely have a permanent effect on political and social culture.

(2) Cities promoted (sometimes to raise institutional awareness or as a result of pressure from social organizations) specific measures to increase opportunities for an active and equal participation of women in PB.

Undoubtedly, the latter has been able to offer a series of creative solutions to the difficulty of realizing gender mainstreaming as a side effect of participatory processes and policies that had no such feature among their initial goals. As the INCLUIR $(2007)^{3}$ project proved through its networking activities, it is almost impossible to find evidence of PB resulting in social inclusion (not only for women but also for those marginalized due to ethnicity, disabilities, migration, age or sociocultural status) unless it was an explicit goal and specific tools were employed to achieve this goal. This second group of PB cases is generally limited by two factors. The first is that their strategies seem to concentrate on increasing the numbers of women participants by reducing visible barriers to their presence rather than on problematizing the balance and quality of power relations. The second is that they deal with narrow issues of women's participation, rather than focus on a wider gender-related series of concerns, intertwining them with issues linked to ethnicity, age, education, parenthood status, disabilities and so on.

\subsection{Including Women in PB}

The Brazilian city of Porto Alegre was among the first to try to monitor and study the presence of women in PB since 1990. During the first 15 years of local PB, the NGO Cidade-Centro De Assessoria e Estudos Urbanos ${ }^{4}$ monitored several aspects of the evolution of this process. Two books were published in 2003 and 2007, the latter being Olhar de Mulher. A Fala das Conselheiras do Orçamento

\footnotetext{
${ }^{3}$ INCLUIR is the acronym of "El Presupuesto Participativo como instrumento de lucha contra la exclusión social y territorial", coordinated by the City of Venice within the EU-funded URBAL programme; Network $n^{\circ} 9$ was developed between 2004 and 2006 and is dedicated to Participatory Budgeting and Local Finances. See more at: http://www.comune.venezia.it (15 March 2014).

${ }^{4}$ See: www.ongcidade.org (15 March 2014).
} 


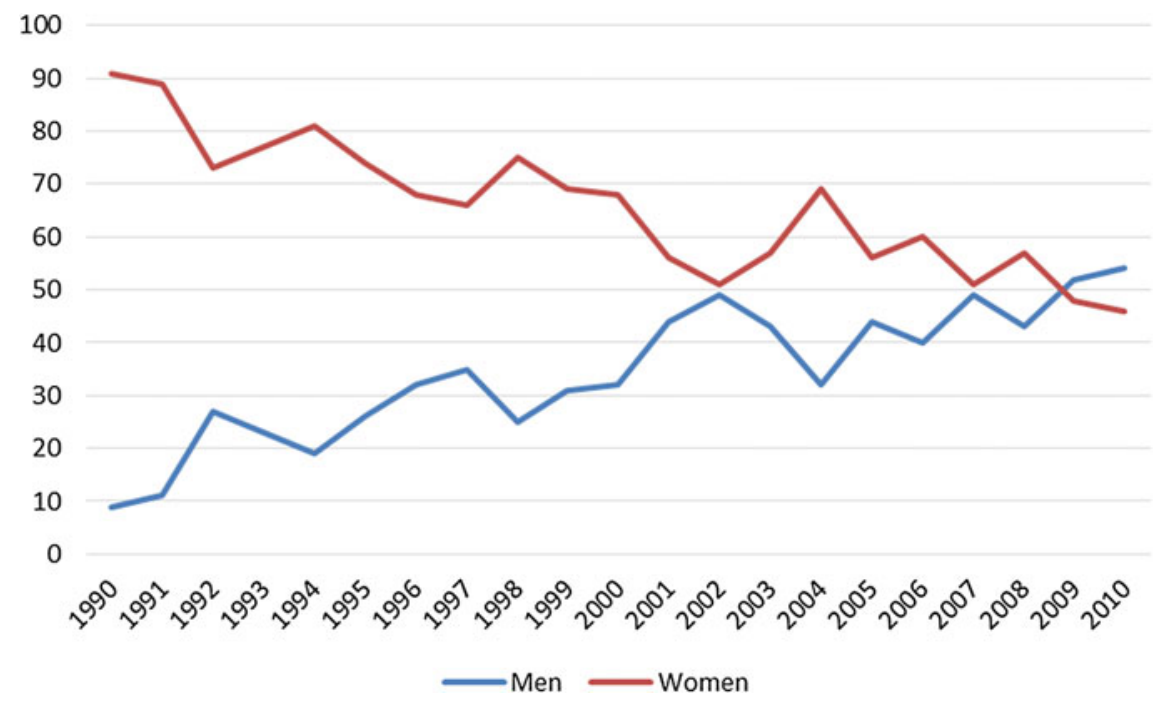

Fig. 3.1 Presence of men and women in the Popular Council (COP) of Participatory Budgeting in Porto Alegre. Source CIDADE-PMPA (2010)

Participativo de Porto Alegre 5 (CICADE 2003, 2007). These materials analysed the slow progress of women to participate in the different institutions, with special attention to slum dwellers, that implemented PB. They showed that while women's numbers increased quickly in the basic territorial assemblies, resistance from men who were afraid of losing their positions of power made obstacles to equality more difficult to conquer in the more representative arenas, such as the PB Council or COP which houses the popular councillors elected from the 17 districts. ${ }^{6}$ By 2005 , women in Porto Alegre already represented $54.5 \%$ of PB participants, but in the COP they only reached such a percentage in 2010 (CIDADE-PMPA 2010).

Interviews with women active in $\mathrm{PB}$ revealed several other elements that explained such dynamics and how they were addressed (Fig. 3.1). For example:

(1) Women tended to concentrate on issues linked to family and the quality of social services in areas such as education, health, social assistance and income generation. They accounted for $80 \%$ of the participants in the Health and Welfare thematic assemblies in 2005 (CIDADE-PMPA 2010).

(2) Women seemed to be largely in the 34-60 age group, while men seemed to be largely in the 16-33 and 60-plus age group.

\footnotetext{
${ }^{5}$ This could be translated as: "Through Women's Eyes. The Speech of Female Councillors on Participatory Budgeting in Porto Alegre".

${ }^{6}$ The COP is made up of 64 citizens elected by the community assemblies during the annual PB process that make the final decisions related to the annual priorities of PB.
} 
(3) Women in leading positions in PB were often single or divorced (62-65\%) and therefore more independent and not requiring men's permissions to participate (Fedozzi 2007).

(4) Many women (especially from the lower social classes) tended to feed prejudices on women's role, often allowing men a monopoly in family representation. ${ }^{7}$

(5) Throughout the first 20 years of PB, women belonging to organized groups (such as NGOs and mothers' clubs) increasingly took part in PB and motivated their members to do the same.

In 2009, such observations were translated into a Manifesto of Action during the Fourth Porto Alegre Conference on Public Policies for Women. Participants envisaged PB as a pivotal political opportunity for building new State-society relations, criticizing the minimal expenditure devoted to specific programmes for women's capacity building. ${ }^{8}$ The existence of 170 nursery schools in 2010 which had cooperation agreements with the municipality was presented as a visible indicator of the effectiveness and specific nature of women's struggles within PB. An additional indicator was the creation of several bottom-up enterprises and cooperatives for women and educational committees. However, participants publicly expressed their doubts over the concept of community, emphasized by public institutions, but used to conceal social differences, especially between the sexes. Additionally, they demanded that new programmes be established to empower women to increase their entrepreneurial capacities in all the spaces of local and non-local' social life and citizenship, far beyond the traditional emphasis on their role in community organizations. ${ }^{9}$ The city of Recife was publicly identified as a model for having created since 2002 a PB thematic Forum for Women that acted as a bridge between policy sectors, linking them to the women's movements rooted in the city.

The transparency and accountability measures guaranteed in all Brazilian participatory budgets including the publication of simplified and understandable versions of general city budgets and multi-annual plans has helped women call for major investments dedicated to their empowerment. This system has been emulated in different cities as a result of pressures from women's movements in different areas of the country and even from abroad.

\footnotetext{
${ }^{7}$ Conclusions presented at the 'IV Conferência Municipal de Políticas Públicas para Mulheres de Porto Alegre'. Diagnóstico e Desafios, 11 and 12 September 2009.

${ }^{8}$ Among the data published in the Conference of 2009 that criticized the declining commitment of the Town Hall in promoting women. It was noted that the Porto Alegre women's programme (one of the 21 programmes into which PB is divided) has always been the smallest and most marginal. As an example, it was revealed in 2008 that out of a 2.8 billion budget (in R\$), only 109,000 R\$ was dedicated to the gender programme, and only $38 \%$ of resources was used.

${ }^{9}$ Conclusion presented at the 'IV Conferência Municipal de Políticas Públicas para Mulheres de Porto Alegre'. Diagnóstico e Desafios, 11 and 12 September 2009.
} 


\subsection{Mainstreaming Gender in PB}

The Brazilian cities of Recife and Fortaleza also conducted specific studies on the presence of women in $\mathrm{PB}$, in order to approve measures to extend gender mainstreaming beyond PB. The central idea of the Recife study was that gender inequalities create different conditions of participation for different subjects. Thus, public policies aimed at gender equality must become structuring elements of PB, whose main value add is breaking the confinement of women to domestic space (Ávila et al. 2006). The subsequent increase in the Women Coordination Commission tasks was considered an opportunity for improving practical features and creating preconditions to increase women's capacity for involvement in PB activities. These programmes included creating specific courses and leaflets on budgeting for women and offering child care facilities during public PB assemblies. The Recife document was also important as it also analysed the limits of a monolithic approach to women's difficulties, stimulating a multi-layered approach to plural and convergent exclusions linked to race and economic conditions of women.

Several of these issues also reappeared in the specific gender sensitive study of PB in Fortaleza (2008) that offered different solutions to similar problems, by creating a Plenary of Segments within PB. This was a special assembly where minority and vulnerable groups such as women who form a majority in numbers but a minority in terms of equality of substantive rights ${ }^{10}$ converged. The Fortaleza strategy dealt with specific issues related to women's equality within a wider policy-oriented approach. These were aimed at increasing gender sensitive institutions, creating spaces to support citizens with different sexual orientations and making their representatives meet in the Encontros da Cidadania (meeting of citizens), where issues of multiple and multi-layered exclusions were discussed.

The Fortaleza analysis of PB from a gender sensitive perspective was an important step in accumulated knowledge and reflection on the value of struggles which led to the approval of urban equipment and facilities (from kindergartens to health and family care centres) that challenged the sexual division of labour. The end result was a reduction of the overload of work for women (Alves/Viana 2008: 47). However, the study acknowledged the existence of obstacles in convincing male PB delegates of the need to approve proposals strictly linked to their priority and visions and to defend children's interests. Its conclusions therefore promoted strengthening measures capable of reinforcing the dimensions of PB as a space for learning and making women's needs and ambitions more visible, increasing their perceived legitimacy and contributing to consolidate their image as political subjects with full rights by continuously questioning inequalities among sexes and those of different sexual orientations.

These Brazilian experiences became a point of reference in other countries, where gender mainstreaming of PB was not pivotal. In Europe, for example, few

\footnotetext{
${ }^{10}$ The study Politicas para as Mulheres em Fortaleza shows that here (between 2005 and 2008) the women represented $67 \%$ of overall participants.
} 
countries (except the UK) took specific measures to improve women's contributions to PB. The PB Unit was a think tank in the UK that, up until 2012, offered consultancy services to most local PBs. It published a small reflection on the issue (Lavan 2006), referring to the Recife study. It also created special training spaces for immigrant women and provided mobile recreation spaces for children, usually in PB venues in some cities. These steps aimed to facilitate the participation of women who had child care responsibilities.

In general, a deeper inequality between women and men has been recognized and addressed with specific measures in neo-Latin Mediterranean countries. For example, in 2004 in Pieve Emanuele, Italy, a small city forged mainly by migrants from Southern Italy, PB process monitoring underlined the scarcity of women's participation (around $20 \%$ ). This was partially because Southern Italian cultures allow men to represent families in public spaces. In an attempt to reverse the situation, the municipality duplicated public meetings, repeating them on the same day at around $5 \mathrm{pm}$ in schools, with a guaranteed extension of children's activities to allow mothers to take part in budget discussions. The strategy achieved excellent results, re-balancing women and men's involvement in PB. In Arezzo and in other Tuscan cities, as well as in Portugal (in Cascais and São Brás de Alportel, for example), mobile play areas and babysitting spaces were organized to allow young families with child care responsibilities to attend PB meetings. In Modena, Italy, an online streaming transmission of public assemblies was undertaken to guarantee the participation of women and young families. In Spain, especially in Andalusia, PBs set specific quotas (of $50 \%$ ) for the election of citizens' delegates. Seville, the first city to experiment with quotas for promoting women's representation, inserted PB in a larger political context, and was equally careful to include gender sensitive issues. PB was explicitly linked to the Vice Mayor's Office for Women, but also provided specific support and visibility to LGBT groups and immigrant communities. It must be stressed that Seville, with Fortaleza, is one of the few cities around the world to have dedicated direct attention to gender differences within its specific PB process, recognizing differences between women of different ages.

\subsection{Overcoming Cultural Barriers}

An interesting experience is from Greater Geraldton in Western Australia. In 2012, the first PB experiment here included a randomly selected committee that guaranteed gender equality. Special meetings were organized for citizens of aboriginal origin, respecting cultural habits, including those related to forbidding direct dialogue among some components of society. During the events, a mobile truck equipped with play areas and computer facilities was offered by the Town Hall to facilitate women's participation.

Among the most interesting experiences in Africa are those of rural villages in Senegal (such as Fissel or Ndiagagnao) where citizens were divided into socially homogeneous groups (women, youngsters, the elderly) to set participants at ease in 
the discussion of their specific needs and proposals. In places where women in representative democracy did not reach $15 \%$ of the elected officials, PB managed to attract almost $50 \%$ women participation, challenging self-censorship-which usually affects women's participation in large meetings - through temporary separation of the smallest target-oriented groups that could, then, later interact with the overall population.

The Training Companion for Participatory Budgeting, published by UN Habitat in 2008 to help disseminate PB in the continent, repeatedly stresses the importance of the cultural dimension, especially gender-biased cultural norms and traditions that influence women's participation in the budgeting process. The handbook calls on local governments to take bold measures to implement women's empowerment and overcome the lack of understanding around local government systems and council management that often affects women more than men. The report notes that some religions forbid women and men from sitting together or, in some instance, working on certain days of the week. In some cultures, one is not allowed to express dissent or criticize higher authorities in public meetings. In others, age is a serious issue where the young people cannot oppose the views of the elders. Therefore, the socio-economic and socio-cultural dimensions call for the local government to be sensitive to diversity among citizens. In addition, effective participation in the budgetary process could be constrained by the language barrier due [to] the multi-ethnic composition of many African countries which calls for the use of indigenous languages during participatory budgeting meetings (UN-HabitatMDP-ESA 2008, vol. I). Even stronger is this extract (Box 3.1).

\section{Box 3.1: The Case of Singida District, Tanzania}

Local tradition and custom holds sway in Singida District. These are often oppressive to women, restricting married women for example from speaking before men, lest they be regarded as prostitutes in the community. Husbands restrict their wives from participating in social and economic activities, and men seize any income generated by women, which leaves them even more dependent on their husbands. Widows may, however, engage in the community decision-making process as they are perceived to be heads of households like men.

It offers some examples aimed at enhancing the links between economic and social policy outcomes and tracking public expenditure against gender and development policy commitments. It also suggests simple measures such as time-tabling PB meetings and choosing venues that would not necessitate significant travel, particularly at night. Scattered grassroots gender budget initiatives that focus on education, health and agriculture are discussed for countries like Malawi, Mozambique, Namibia, South Africa, Tanzania, Uganda, Zambia and Zimbabwe. Specifically, the most quoted African example is that of the Gender Budget Initiative in Tanzania, 
which resulted in budget guidelines instructing line ministries to submit gender sensitive budgets. Another frequent example concerns Uganda, namely the District Development Project (DDP), promoted at the beginning of the millennium by the Ministry of Gender, Labour and Social Development and the Ministry of Local Government. According to the new strategy, all sub-counties and districts are in possession of well-outlined planning and budgeting guides that emphasize a bottom-up approach to the soliciting of planning ideas and their prioritization. Gender inclusion in planning and budgeting systems and processes, through fair representation of women in public meetings, is emphasized via recommendations for correcting education and career imbalances that require increased education for girls and a cut in the illiteracy rate, currently at an average of $60 \%$ for women and $38 \%$ for men. It has opened the participation of women in non-traditional areas such as the construction of health units and other facilities (UN-Habitat/MDP-ESA 2008: 55). However, most examples of local institutional commitment on gender mainstreaming stem from Latin American experiences. The four most internationally quoted experiences are Cotacachi Canton Municipality (Ecuador), Rosario (Argentina), Santo André (Brazil) and the Peruvian city of Villa El Salvador (Ortiz 2008).

\subsection{Three Success Stories}

Although the Cotacachi case has been weakened by drastic changes since $2009,{ }^{11}$ the typical romanticizing inertia of networking exchanges continues to consider it one of the world's most interesting case studies of gender sensitive PB due to the outcomes between 2001-2008. Santa Ana de Cotacachi is a municipality located in the Imbabura Province in Ecuador. It has more than 37,250 inhabitants of which $80 \%$ live in rural areas. It has always been marked by ethnic and cultural diversity, of which around $60 \%$ of the population are indigenous Quechua, 35\% white-mestizo, and $5 \%$ Afro-Ecuadorian (Meyers 2005). Its rural population had traditionally been excluded from development processes with poor access to potable water and sewerage. It had one of the highest child mortality rates in the country. With an annual budget of around US\$3 million, the municipality was run, until 1996, by the white-mestizo community, as the indigenous majority tended to be politically subordinate, economically pauperized and socially excluded. Furthermore segregation was especially hitting indigenous women in the rural area (UCLG 2011). The election of the indigenous Mayor Auki Tituaña in 1996, and his subsequent re-election in 2000 and 2004, modified local governmental structures, leading to the creation of Women's Coordinating Committees and a series of Annual Cantonal

\footnotetext{
${ }^{11}$ The main changes - after elections led to a different political coalition — have been in the area of administrative reorganization of political responsibilities, which marginalized participation in the political strategy of the new mayor. For more details see: http://www.uclg-cisdp.org/es/ observatorio/la-inclusi\%C3\%B3n-de-mujeres-ind\%C3\%ADgenas-en-un-proceso-de-presupuestoparticipativo-local (15 March 2014).
} 
Unity Assemblies. The creation of PB in 2002 stated three main intertwined goals: (1) promote social, ethnic, inter-generational and gender-based participation and organization; (2) bring transparency to municipal budget management; and (3) achieve self-management that values the community's economic contribution. An Oversight Committee made up of community members was created in 2003 ensuring that the implementation of jointly decided measures was socially controlled. In the same year, gender-differentiated and positive discrimination measures shaped specific workshops aimed at creating a collaborative environment where indigenous women could feel at ease and could overcome traditional passive behaviour when confronted in a public scene.

As a result, the participation of indigenous women quickly increased and their community organizing capacity was strengthened, through a careful use of their native languages and pedagogical resources employing colours, local symbols and other daily materials. The ascent and empowerment of the women of Cotacachi in PB led to a series of transformations in municipal management, policies and back office procedures. This was supported by special training sessions for municipal technical teams who received specialized skills in participatory techniques and were reinforced by mostly women members. Other transformations included a new arrangement of the Cantonal Development Plan, the Cantonal Health Plan, the Environmental Management Plan, the Parish Plans, and the Community Plans. In 2003, the Yes I can campaign was launched, involving 1,667 people, $65 \%$ of whom were women who were taught to read and write (UCLG 2011). Since then, $10 \%$ of all indigenous women and $20 \%$ of all adult women have been taught to read through this programme with the UN declaring Cotacachi the first illiteracy-free canton in Ecuador.

Since the PB application, over two-thirds of municipal resources have been allocated to rural areas, in radical contrast to the formulas previously applied. Significant improvements have been made in rural electrification with $95 \%$ coverage in the sub-tropical area, while $12 \%$ of the annual budget has been allocated to basic sanitation. In a few years, infant mortality has been reduced to zero, and the promotion of traditional medicine was approved, placing value on ancestral indigenous knowledge and equipping informal workers in the area with these skills. As the OIDP Best Practices distinction ${ }^{12}$ in 2006 stated, the Cotacachi experience went far beyond the scope of distributing and controlling public resources; it achieved durable economic, political, social and cultural impacts. It underlined the importance of political will as a precondition for fostering the development of a real participatory culture in local society. It showed how institutional actors could empower people, giving them a genuine space to define their policies and control the implementation of their projects. The degree of social integration and sustainability that PB managed to achieve guaranteed the continuation of several of its features, even after the electoral defeat of Mayor Auki Tituaña in April 2009.

\footnotetext{
${ }^{12}$ The OIDP "Best Practices in Citizen Participation" distinction was created in 2006 by the International Observatory of Participatory Democracy. See: http://www.oidp.net/en/projects/oidpdistinction-best-practice-in-citizen-participation/ (15 March 2014).
} 
In the Argentinean city of Rosario, the results of an interesting hybridization of PB with gender sensitive policies were also very promising and sustainable. ${ }^{13}$ Its articulation, networking capacity and considerable investments in international diplomacy made it an international model to be emulated. In this case, PB started in 2002, following a methodology adapted from Porto Alegre (Roeder 2010). In 2003, the municipality decided to develop a gender budgeting strategy, soon supported by the UNIFEM gender budgeting programme. This included several different activities for increasing women's involvement in PB. It also included citizen activities such as training civil servants, both women and men, to be more sensitive to gender issues, public campaigns to combat gender prejudices and better interrelated PB and other actor-centred activities aimed at promoting more gender responsible public policies (Bloj 2014). Gradually, all districts were involved in the experiments and a growing number of projects were adopted, with investments of more than US\$ 800,000 per year. Among other measures, a system of quotas was established to promote gender equality in the election of citizen delegates in PB. The main goal of such transformation was to disseminate mental change, i.e., a new way of framing public issues in relation to gender (Sintomer et al. 2013). This could be more sustainable than merely increasing women's involvement in PB, which is an important but not sufficient condition, given that it alone cannot transform relationships between women and men in the participatory arena (UNIFEM/UNV 2009).

The UN Development Fund for Women (UNIFEM), which later became UN Women, an agency dedicated to gender equality and the empowerment of women (see: www.unwomen.org), has played an important role in promoting experiences, particularly in Latin America, that try to merge PB with principles of gender responsive budgeting. Rosario and Recife benefited from this support. Today, several cities and social organizations around the world can take advantage of a specific website called Gender and Budgeting. ${ }^{14}$ It was developed with the aim of providing a platform for managing and sharing knowledge on Gender Responsive Budgeting experiences in Latin American and the Caribbean.

Finally, it is worth highlighting the positive achievements of one of the latest generations of $\mathrm{PB}$ in relation to the issue of gender mainstreaming - that of the United States. In New York, various experiences have benefited from the support of the New York Women's Foundation and community organizations such as Community Voice Heard and WORTH (Women on the Rise Telling her Story). Since early 2011, special attention has been paid to the intersection between gender, economic status, race and age issues. As a result, and as stated in the Second Annual Research and Evaluation Report on Participatory Budgeting (PBP 2013) in New York City, over $60 \%$ of the more than 13,000 who voted on how to spend almost US $\$ 10$ million of public money in 2012-2013 were women, most being people of colour, Asian, or Latino and loweror middle-income earners. They were motivated by immigrants and formerly

\footnotetext{
${ }^{13}$ See Box 9: Participatory Budgeting and Gender Mainstreaming: The Rosario Experiment in Sintomer et al. (2013).

${ }^{14} \mathrm{See}$ : http://www.presupuestoygenero.net (15 March 2014).
} 
incarcerated offenders, often dispossessed of political rights in the US, showing the inclusive face of participatory democracy and its capacity to address multiple layers of exclusion. An interesting feature that emerged from monitoring participants in New York's PB was that women were more likely to participate in all the stages of the PB process compared to men, as evidenced by the fact that between 2012-2013 women were $66 \%$ of neighbourhood assembly participants, $60 \%$ of budget delegates and $62 \%$ of voters in the PB process. Furthermore, women did not just attend PB events in large numbers, but were also active in their participation: $92 \%$ declared that they spoke during the different phases of PB community organization and during the small group discussions at neighbourhood assemblies. As stated in the detailed analysis of District 39 results (ibid.: 84), community-based institutions have been critical in building trust and engaging women in civic participation. Therefore, it is possible to say that PB challenged the patriarchal paradigm, bringing about a significant increase in engagement, when compared to 2009 local elections where only $53 \%$ of voters were women. ${ }^{15}$

\subsection{Challenges to Gender Sensitive PB}

PB has long been considered a gender sensitive tool, or at least closely related to gender budgeting and other approaches, in terms of monitoring public finances and studying the impact of revenue and expenditure policy on women and men to stimulate greater gender equality. ${ }^{16}$ However, data from international studies shows the opposite; women's participation was much lower than their men counterparts, especially in the higher steps of PB, which usually include some degree of representation and some power in setting the final agenda for PB decisions.

Such romanticizing of PB is possibly linked to its potential, as a result of which it is considered an important tool for the empowerment of social actors traditionally marginalized from decision making in public policies and projects. PB includes a series of distinguishing features such as more profound methodological and communicative process compared to previous participation formulas. These make it seem richer and more radical in challenging norms and addressing the decreasing perceived legitimacy of political/administrative institutions and the individualistic tendencies of society. ${ }^{17}$ The imagined components of PB - transparency, accountability and responsiveness - appear to be suitable tools to rebuild mutual trust

\footnotetext{
${ }^{15}$ In District 39, $97 \%$ of women spoke during small group discussions, $80 \%$ made specific budget proposals and $33 \%$ volunteered to be budget delegates (p. 84 of the 2013 Report).

${ }^{16}$ See: http://www.partizipation.at/part_budget0.html (15 March 2014).

${ }^{17}$ An interesting tale, circulated by the Director of the PB Project Josh Lerner, tells of a woman he interviewed in Rosario for his Ph.D. thesis who proudly affirmed that she was able to 'divorce' her husband owing to Rosario PB. PB enhanced her social relations, allowing her to feel supported, and she could leave the suffering and isolation she lived in when she felt weaker due to lack of friends and community support.
} 
between politics and the social sphere. These would also facilitate tracking expenditure and its impact on social inclusion, including gender equality and empowerment objectives pursued by important international documents such as the Beijing Declaration and the Millennium Development Goals. ${ }^{18}$ It is now clear that without specific and coherent measures to make these goals effective, PB could turn into another unfulfilled promise, at least in relation to gender mainstreaming (Bobbio 1987; INCLUIR 2007). Many PB experiences have achieved women's numeric participation; unfortunately, this could prevent action to make them more responsive in terms of gender mainstreaming.

The numeric presence of women in participatory processes can create an illusion of equality, ignoring the differential of power and sociopolitical recognitions between sexes and other gender-related issues. Furthermore, these could overlook the enormous impact of gender-related exclusions when combined with other exclusions related to race, ethnicity, age, parental status, educational or socio-economic conditions (Ribeiro 2000; Martins Costa 2003).

As the Third Gold Report on Decentralization states, 'many of the most dramatic inequalities are related to housing, living conditions and access to basic services, which have knock-on effects on other inequalities, particularly gender inequalities' (UCLG 2013: 111). In this sense, PB is considered a possible solution, capable of triggering and inciting a virtuous circle that can gradually improve living conditions, enhance citizenship, and create feelings of ownership and belonging to a territory among vulnerable social groups (Cabannes 2014). PB also adds value to invisible urban equipment such as underground sewerage networks and water facilities, making them marketable from a political point of view. This allows approaches on basic needs to take on a more central role in the shaping of public policies.

However, these unequal living conditions can hinder the participation of specific social groups if participatory processes do not incorporate concrete measures to overcome them. For example, an important assessment of PB was conducted in Brazil in 2004 by the Inter-American Development Bank (2004) and the Centre for Urban Development Studies of the Graduate School of Design at Harvard University. It showed how timetables and venues of PB public meetings could act as barriers to equal participation by women. It also showed how scale could influence the costs of attending PB sessions and their inclusiveness, especially given that, at the state level and in the municipalities with large rural zones, the gender dimension of participation is particularly striking, since women are more reluctant to travel too far from their homes (Inter-American Development Bank 2004: 25$).{ }^{19}$

\footnotetext{
${ }^{18}$ Especially, see Article 13 of Beijing Declaration and the MDG 3.

${ }^{19}$ Scale and distance have an impact on the participation of women, which falls off rapidly the farther away from the community public meetings are held (Inter-American Development Bank 2004: 38), since physical and financial cost of participation increase with distance from home and affect representation (particularly of women) in the forum of delegates and COP (Inter-American Development Bank 2004: 34).
} 
Some previously quoted studies are specifically interested in analysing the obstacles to women's participation in PB and have revealed multiple reasons for forced self-exclusion from some or all of its different stages. These proved useful in adopting concrete measures to lower access barriers, such as introducing technological tools to facilitate distance-participation. Nevertheless, it has not yet been proved that such measures genuinely work to overcome participation barriers. A study on the Belo Horizonte electronic PB (PMBH 2012) showed that participation among the 25,378 voters of ePB was gender balanced in every age group (49-50 \%). It is, however, inconclusive on the advantage for women's inclusion in such a technological rearrangement of PB. The national study conducted by the OPtar project (2013) in Portugal showed that women represented on average $48.8 \%$ of overall participants in public assemblies but only $44.5 \%$ of participants in online activities. The differences between each targeted PB provided inconclusive results in terms of structural reasons for such a dynamic. This suggests that local contexts and conditions weigh heavily on such results and often reproduce in participatory arenas exclusions/seclusions that are strongly rooted in the elected institutions of representative democracy. ${ }^{20}$ Similarly, the project has been unable to prove that measures like babysitting facilities have had concrete effects on women's participation, even if it recognizes that they are important for fulfilling rights.

The last examples reinforce the need for further studies and for new methodologies, such as participatory observation, that could offer explanations for the persistent inequality in numbers and, more importantly, in power. Several PB processes have adopted measures of positive discrimination based on quotas, on specific actor-centric processes targeting women, or on the delivery of special training sessions and support materials to increase women's presence in PB. However, detailed monitoring reports and analyses are still missing. These could provide evidence of the effects of such measures not only on numbers measuring women's presence in processes but the quality of their commitment and the resulting output.

Reports published annually in Porto Alegre or New York are interesting starting points but they must be complemented with monitoring reports. These must link the presence of women to their degree of activism, the type and quality of proposals presented, and to their major or minor capacity for attracting general attention and votes of larger audiences during PB voting phases.

\footnotetext{
${ }^{20}$ For example, in PB in Amadora and Leça da Palmeira district in Matosinhos Municipality, the presence of women in public assemblies (reduced respectively to 38.2 and to $11.9 \%$ ) can be explained by the fact that mostly members of elected local district councils participate in these two places, thus reproducing the dynamic of Portuguese representative institutions where the presence of women is scarce.
} 


\subsection{Conclusion: Towards a More Holistic Research Agenda}

Much is still lacking in terms of analyses of the relations between women's movements and the transformation of institutionalized spaces of participation. This would help understand the capacity of social self-mobilization, which Pedro Ibarra (2007) called participation by irruption to influence and modify the spaces of participation by invitation (ibid.) that are often top-down creations. As Santos advocates (2007), such research must adopt and update a feminist perspective and understand the historical relations between State and society in a specific territory, especially its recent improvements through the connection with gender sensitive participatory processes. Such a change would be even more important at a time when a new form of hybridization has occurred between PB and gender mainstreaming to tackle the root causes of inequalities between men and women, encouraging the development of comprehensive programmes that target both men and women, and seeking to change traditional views (Sintomer et al. 2013).

Unfortunately, today, a wave of PB experiences tend towards a hyper-simplification of proposing and voting procedures for fear of losing participants by asking them to fill in too many forms and provide personal data. Such experiences especially active in Portugal and Germany through the use of internet and SMS voting, seriously compromise the possibility of knowing who participates in PB. This would make it impossible in the future to set adequate measures to rebalance participants according to their sex, age, race or socio-economic and cultural status.

As stated in Sintomer et al. (2013: 36), 'strangely enough, although they are characterized by elective affinities, PB has not merged with gender mainstreaming very often', except in some instances in Latin America highlighted in this chapter. This can be attributed to the meagre contributions of local political institutions, universities, research centres, social organizations and international institutions that have scarcely supported or stimulated such a merging of models to an innovative culture of gender mainstreaming through PB.

In the past, some important international institutions such as the Urban Management Program of the United Nations, the Friedrich Ebert Foundation ${ }^{21}$ and UN Women were active in supporting pilot initiatives. However, in some cases, ${ }^{22}$ their regard for gender inequalities was too simplified. Almost 25 years after the first PB experience, the goal of bridging inequalities between women and men still

\footnotetext{
${ }^{21}$ In June 1999, the Friedrich Ebert Foundation in Porto Alegre conducted the first workshop on 'Public Budget and Gender Policies' to strengthen Labour municipal governments to include gender issues in the planning and implementation of municipal policies.

${ }^{22}$ See Indicator no 7 in the UMP document (2004), "Participatory Budgeting: Conceptual Framework and Analysis of its Contribution to Urban Governance and the Millennium Development Goals". It is entitled 'Percentage of women councillors in local authorities' and somehow reduces the understanding of power differences that separate men from women in participatory processes.
} 
seems to lack adequate attention in the transformation and spread of PB around the planet.

One of the most complete documents on gender and PB has been produced by the highly qualified English think tank The PB Unit with the Manchester Women Network (Lavan 2006). It notes the critical need to concentrate on the different uses of the city by women and men, such as the qualitative aspects of equality and the internal deliberative equality (Santos 2007) of analysed PB processes. Moreover, such elements will have to be linked to an integrated and complex interpretation of social exclusion understood in its multi-layered and articulated dimensions. It will also have to be connected to existing interrelations between the active presence of women in participatory processes and the struggles of women's movements in the same territory. Finally, it will be important to try to measure the effectiveness of women's proposals, presented through PB, to change city models and urban cultures, more than just improving single services and urban spaces.

Until now, several of these goals have not been explicitly posed; others have been hesitantly traced. However, the analysis remains inconclusive, the research methods anecdotal instead of evidence-based and, importantly, comparative studies rare. Research could analyse the relationship between PB and gender sensitive issues beyond single case studies and specific contexts to search for common problems and shared solutions among the thousands of PB experiences that are growing daily around the planet.

\section{References}

Alvarez, Sonia, 1991: Engendering Democracy in Brazil: Women's Movements in Transition Politics (Princeton: Princeton University Press).

Alves, Maria Elaene Rodrigues; Viana, Raquel, 2008: Politicas para as Mulheres em Fortaleza. Desafios para a Igualdade [Policies for Women in Fortaleza. Challenges for Equality] (Fortaleza: Prefeitura Municipal de Fortaleza/Coordenadoria Especial de Politicas Publicas para as Mulheres).

Appadurai, Arjun, 1991: "Global Ethnoscapes: Notes and Queries for a Transnational Anthropology", in: Fox, Richard (Ed.): Recapturing Anthropology: Working in the Present (Santa Fe NM: School of American Research Press): 191-210.

Ávila, Maria B.; Santos, Joana; Ferreira, Veronica, 2006: Mulheres no Orçamento Participativo: Estudo da Experiência de Recife, na Gestão 2001-2004 [Women in Participatory Budgeting: Study of the Experience in Recife, 2001-2004] (Prefeitura de Recife: UNIFEM).

Avritzer, Leonardo, 2007: Relatorio de Pesquisa "Participação e Distribuição nas Políticas Públicas do Nordeste [Research Report "Participation and Distribution in Public Policies of the Northeast]" (Belo Horizonte: UFMG/Prodep): 9-44.

Bloj, Cristina, 2014: "Participatory Budgets in Argentina: Evaluation of a Process in Expansion", in: Dias, Nelson (Ed.): Hope for Democracy: 25 Years of Participatory Budgeting Worldwide (São brás de Alportel: In-Loco Ed.): 135-152; at: https://democracyspotdotnet.files.wordpress. com/2014/06/op25anos-en-20maio20141.pdf (15 March 2014).

Bobbio, Norberto, 1987: The Future of Democracy. A Defence of the Rules of the Game (Minneapolis: University of Minnesota). 
Cabannes, Yves, 2014: Contribution of Participatory Budgeting to the Provision and Management of Basic Services at Municipal Level. Municipal Practices and Evidence from the Field. Background paper for UCLG Gold III, first draft (London: International Institute for Environment and Development IIED).

CIDADE, 2003: Fazendo Política. Perfil das Conselheiras e Conselheiros do Orçamento Participativo 2002/2003 [Policy Making. Profile of Women and Men Councillors of Participatory Budget 2002/2003] (Porto Alegre: CIDADE).

CIDADE, 2007: Olhar de Mulher. A Fala das Conselheiras do Orçamento Participativo de Porto Alegre [Through Women's Eyes. The Speech of Female Councillors of the Participatory Budget in Porto Alegre] (Porto Alegre: CIDADE).

CIDADE-PMPA, 2010: "Mulheres no Orçamento Participativo: Conquistas e Desafios [Women in the Participatory Budget: Achievements and Challenges]", in: Atas da IV Conferencia de Politicas Publicas de Porto Alegre para Mulheres, 11-12 September 2009 (Porto Alegre: Preffeitura Municipal de Porto Alegre).

Fedozzi, Luciano, 2007: Observando o Orçamento Participativo de Porto Alegre [Observing Participatory Budgeting at Porto Alegre] (Porto Alegre: Tomo Ed.).

Gutiérrez-Barbarrusa, Virginia (2012), "Análisis Sobre la Participación en los Presupuestos Participativos [Analysis of Participation in Participatory Budgets]" in: Allegretti, G. (Compilador), Estudio Comparado de los Presupuestos Participativos en República Dominicana, España y Uruguay [Comparative Study of Participatory Budgeting in Dominican Republic, Spain and Uruguay] Malaga: CEDMA, pp. 147-193.

INCLUIR, 2007: El Presupuesto Participativo como Instrumento de Lucha contra la Exclusión Social y Territorial [Participatory Budgeting as a Tool in the Fight against Social and Territorial Exclusion], PROYECTO INCLUIR/URBAL 9 and Comune di Venezia, Venezia (Venice: Comune di Venezia).

Inter-American Development Bank, 2004: Assessment of Participatory Budgeting in Brazil, (Cambridge, Mass.: Harvard University, Center for Urban Development Studies/Graduate School of Design).

Lavan, Kezia, 2006: Towards Gender-Sensitive Participatory Budgeting, Discussion Paper (Manchester: Participatory Budgeting Unit).

Martins Costa, Delaine, 2003: "A Gramática do Orçamento a partir das Perspectivas de Gênero e Raça: Considerações Preliminares [The Grammar of the Budget from the Perspectives of Gender and Race: Preliminary Considerations]", Paper for the VIII Congreso Internacional del CLAD sobre la Reforma del Estado y de la Administración Pública, Panamá, 28-31 October.

Meyers, Rodia, 2005: Cotacachi: Manual de Presupuesto Participativo [Cotacachi: Manual of Participatory Budgeting] (Cotacachi: Municipio de Cotacachi).

Ortiz, Barbara, 2008: "Mujer Ciudadana = Mujer Empoderada $[$ Woman Citizen = Woman Empowered]" (Master Thesis, Lima: PRGEPP/FLACSO).

PBP, 2013: Second Annual Research and Evaluation Report on Participatory Budgeting (New York: The Participatory Budgeting Project).

PMBH-Prefeitura Municipal de Belo Horizonte, 2012: Relatório do Resultado da Votação do OP Digital 2011 [Report on the Voting Outcomes of Digital Participatory Budgeting 2011] (Belo Horizonte: PMBH).

Projeto OPtar, 2013: Relatorio de Pesquisa do Projeto Optar [Research Report of the OPtar Project] (Coimbra: CES).

Ribeiro, Matilde, 2000: "Orçamento Participativo: Panorama Geral e Referenciais Sobre Gênero e Raça [Participatory Budget: Overview and Benchmarks on Gender and Race]", in: Proposta, $\mathrm{n}^{\circ} 84 / 85$ (March/August).

Roeder, Eva, 2010: Der Bürgerhaushalt von Rosario [Participative Budgeting of Rosario] (Münster: Lit Verlag).

Santos, Cecilia McDowell, 2007: "Democracia Participativa e Género. Notas para uma Agenda de Pesquisa Feminist [Participatory Democracy and Gender. Notes for a Feminist Research Agenda]", in: Avritzer, Leonardo. (Ed.): A Participação Social no Nordeste [Social Participation in the Northeast] (Belo Horizonte: UFMG Editora): 237-254. 
Scott, Joan, 1988: Gender and the Politics of History (New York: Columbia University Press).

Sintomer, Yves; Allegretti, Giovanni, 2009: I Bilanci Partecipativi in Europa. Nuove Esperienze Democratiche nel Vecchio Continente [Participatory Budgeting in Europe. New Democratic Experiences in the Old Continent] (Rome: Ediesse).

Sintomer, Yves; Allegretti, Giovanni, 2014: Os Orçamentos Participativos na Europa. Entre Democracia Participativa e Modernização dos Serviços Públicos [Participatory Budgeting in Europe. Between Participatory Democracy and Modernization of Public Services] (Coimbra: Almedina).

Sintomer, Yves; Allegretti, Giovanni; Herzberg, Carsten; Röcke, Anja, 2013: Participatory Budgeting Worldwide - A Study (Bonn: Engagement Global/GIZ).

Sintomer, Yves; Ganuza, Ernesto, 2011: Democracia Participativa y Modernización de los Servicios Públicos. Investigación Sobre las Experiencias de Presupuesto Participativo en Europa [Participatory Democracy and Modernization of Public Services. Research on Participatory Budgeting Experiences in Europe] (Amsterdam: TNI).

UCLG, 2011: "Cotacachi, Ecuador: The Inclusion of Indigenous Women in a Local Participatory Budgeting Process-Inclusive Cities Observatory, Barcelona"; at: http://www.uclg-cisdp.org/ sites/default/files/Cotacachi_2010_en_final.pdf (15 March 2014).

UCLG, 2013: GOLD III - Basic Services for all in an Urbanizing World. Third Global Report of United Cities and Local Governments on Local Democracy and Decentralization-Executive Summary (Barcelona: UCLG).

UN-Habitat; MDP-ESA, 2008: Participatory Budgeting in Africa: A Training Companion with Cases from Eastern and Southern Africa-Vol. I and II, Kenya and Zimbabwe (Nairobi/Harare: UN-Habitat-MDP-ESA).

UNIFEM/UNV, 2009: Experiencias de Participación de las Mujeres para Impulsar el Desarrollo Local con Equidad. Sistematización del Proyecto Conjunto UNIFEM-UNV Presupuestos Sensibles a Género: Visibilizando la Contribución Voluntaria de las Mujeres al Desarrollo de Latinoamérica [Experiences of Women's Participation to Encourage Local Development with Equity. Systematization of the Project UNIFEM-UNV Gender-Responsive Budgeting: Making Visible the Voluntary Contribution of Women to the Development of Latin America] Cuaderno de trabajo 9 (Quito: UNIFEM). 